\title{
An annotated bibliography of C.J. van der Klaauw with notes on the impact of his work
}

\author{
Jacob L. Dubbeldam
}

Received: 11 January 2007 / Accepted: 7 February 2007/ Published online: 9 March 2007

(C) Springer Science+Business Media B.V. 2007

\begin{abstract}
Van der Klaauw was a professor of Descriptive Zoology in the period 1934-1958. This paper presents a concise annotated overview of his publications. In his work three main topics can be recognized: comparative anatomy of the mammalian auditory region, theoretical studies about ecology and ecological morphology, and vertebrate functional morphology. In particular van der Klaauw developed new concepts on functional morphology, based upon a holistic approach. A series of studies in functional morphology of Vertebrates by his students is added. An overview of recent morphological and theoretical studies show that this new approach had a long lasting impact in studies of functional morphology.
\end{abstract}

Keywords Comparative anatomy $\cdot$ Tympanic region $\cdot$ Ecology Ecological morphology $\cdot$ Functional morphology

\section{Introduction}

In 1994 the Zoological Laboratory of Leiden University, home of the newly established Institute of Evolutionary and Ecological Sciences (IEES), was renamed Van der Klaauw Laboratory. This was done in honor of C.J. van der Klaauw (1893-1972), professor of Descriptive Zoology and director of the Zoological Laboratory in the years 1934-1959. Several lines of research were initiated and stimulated during his directorate: histology, ethology, ecology and theoretical biology. He spent most of his scientific life at Leiden University. His main own work was in animal morphology, but he made significant

J. L. Dubbeldam $(\bowtie)$

Institute of Biology, Leiden University, Kaiserstraat 63, Leiden 2311GP, The Netherlands e-mail: j.l.dubbeldam@quicknet.nl 
contributions to other fields, in particular to that of theoretical biology. He was one of the founders of the Jan van der Hoeven Stichting voor Theoretische Biologie (the Jan van der Hoeven Foundation for Theoretical Biology) encompassing philosophy of biology and methodology, and mathematical biology; v/dkl $64^{1}$ ). This foundation publishes the journal Acta Biotheoretica and in the past the Bibliotheca Biotheoretica. Van der Klaauw was also one of the founders of the Museum for the History of Science in Leiden, now the Boerhaave Museum; he published several papers about items from the museum (v/dkl 54, 65, 67, 70). In this overview his main scientific contributions will be summarized and the impact on later work of other researchers reviewed.

A concise overview of his carreer can be found in Boschma (1958) and Brongersma (1972). Van der Klaauw was born in Amsterdam on November 16th, 1893. He studied biology at Leiden University, where he defended his $\mathrm{PhD}$ thesis in 1922.He was appointed assistant in 1919, curator in 1922, external university teacher in 1923, reader (associate professor) in 1931 and full professor in 1934, respectively. During the war he was taken hostage by the German occupying government. He retired in January 1959, but kept writing scientific papers. In 1947 he was appointed member of the Royal Dutch Academy of sciences.

Lately things have been changing in Leiden; the IEES has been incorporated in the newly established Institute of Biology and will be leaving the Van der Klaauw Laboratory shortly. It was the last natural science building in down-town Leiden. This moment seems appropriate for an evaluation of the contributions of van der Klaauw to our knowledge and understanding of various fields of biology.

\section{Important scientific contributions}

Van der Klaauw was in the first place a morphologist with a special interest in craniology. In his public lecture accepting the position of reader he discussed the place of morphology in biology (v/d kl, 37). After an overview of biological subdisciplines in relation to morphology he states that opinions diverge about the question what should be considered to belong to morphology. Van der Klaauw recognized that morphology has mainly a propedeutic significance for other biological subdisciplines. As such it will always be valuable for these areas. As for morphology in its own right he considered comparative anatomy to be the dominant field with emphasis on typology in an idealistic sense. Much of the work of van der Klaauw is characterized by a typological approach, even when he enters the fields of ecological and functional morphology.

\footnotetext{
1 The papers of Van der Klaauw will be referred to as $\mathrm{v} / \mathrm{dkl}+$ the number of the corresponding publication, thus: v/dkl 1 (his first publication). 
Later on Van der Klaauw wrote the introductory chapter in the Dutch Textbook on Comparative Anatomy of Vertebrates (v/d kl 73). In this introduction he distinguished six morphological subdisciplines: descriptive anatomy, comparative anatomy, functional anatomy, ecological morphology, ontogeny and architectonic (Bauplan-) or synthetic morphology. We will consider several of these subdisciplines in the context of Van der Klaauw's scientific work. He did not mention an evolutionary morphology. This does not imply that Van der Klaauw denied the importance of evolutionary theory. He concludes his introduction with the statement that the future program for morphology should be 'the phylogeny of the architecture (building plan) of the form, which should be considered together with the function as an unity'. In his opinion, however, evolutionary theory had not yet explanatory power in morphology.

Van der Klaauw's contributions to the field of morphology concerned several topics. His early work focused upon the tympanic region in mammals. A second subject concerned the basics of ecology and ecological morphology. In the third place he laid down the principles of functional morphology that were later elaborated by Dullemeijer and his coworkers (Leiden school of morphology, see Dubbeldam et al. 1989). The importance of Van der Klaauw's contributions has also been recognized by other scientists. For example, in 1993 Hanken and Hall published a 3-volumes book about the skull; references to work of van der Klaauw are found in several chapters dealing with different aspects of skull morphology (v/dkl 6, 35, 77, 78, 84, 87, 100). The three topics mentioned above will be reviewed concisely in the following sections; also the impact of his work on later and current research will be considered.

Finally, Van der Klaauw produced hand-outs about his lectures on zoomorphology. After his retirement he published part of these lecture notes. So, finally we will have a short look at these notes as these are characteristic for the systematic approach Van der Klaauw used in his scientific work and teaching.

Van der Klaauw was not only a zoomorphologist, but also had great interest in theoretical issues in connection with the schools of morphology, in particular those of Lubosch and Meyer-Abich (e.g., v/dkl 38, 39, 55). This aspect has been discussed before (Trienes 1988). Trienes argued that van der Klaauw developed his concept of holistic biology influenced by, and in confrontation with the German school of idealistic morphology of Lubosch and MeijerAbich. The holistic approach led in the long term to the theory of functional components thus offering an alternative to the reductionist experimental approach. We will not repeat the argumentation of Trienes, but indicate the development in van der Klaauw's thinking in the following sections.

\section{Studies on the bulla auditiva and neighbouring structures}

The first line of research was a continuation of the work of his professor (van Kampen, 1905) and concerned the auditory region of the mammalian 
skull. At that time comparative anatomy was a dominant scientific field. The main question concerned the homology of anatomical elements throughout the classes of Vertebrates. The auditory system of the mammals, including the status of the ossicles and other bony elements were subject of many studies (refs in v/dkl 8). Van der Klaauw participated in the discussions (e.g., v/dkl 6, 8.). His most important contribution, however, concerned the ventral bony wall of the cavum tympani, i.e., the bulla auditiva or bulla ossea. Van Kampen compared this region in a series of adult mammals. Van der Klaauw focussed on the ontogenetic development of this region thus adding a new set of data (v/dkl 3). Later on he expanded his research into the field of phylogeny studying fossil skulls. We will have a short look at both aspects.

\subsection{Ontogeny of the bulla auditiva}

The bulla auditiva had already been studied by several authors (see v/d kl 3 ). The central question concerned the homology of the bony elements of the mammalian auditory region with elements in the reptilian skull. Several elements contribute to the formation of this bulla, such as tympanicum, petrosum, alisphenoid, basisphenoid etc. (v/dkl 66, 74). In some mammals, however, the ventral wall is formed (in part) by a separate element, the entotympanicum. If this ventral wall in mammals is considered a new formation, the question rises whether the entotympanicumis is also a new element and not derived from elements already present in reptilian ancestors. On basis of his comparative studies van Kampen (1905) had concluded that the entotympanicum was a new element without a homologon in the reptiles. Some of his considerations: the entotympanicum appears late in the ontogeny, it is hardly recognizable in Monotremata and Insectivores and only modestly developed in Marsupials. On account of his ontogenetic studies Van der Klaauw (v/dkl 3) concluded that the entotympanicum consists ontogenetically of two elements, that he named the rostral and the caudal entotympanicum. The rostral part is initially part of the cartilage of the tuba auditiva. The caudal entotympanicum develops in the ventral wall of the cavum tympani, has a secondary connection with the tympanohyale and may be considered a derivative of Reichert's cartilage. The caudal entotympanicum is assumed to form initially the ventral cover of the hind room of the cavum tympani. Only later on it participates in covering the ventral wall of the rostral part of the tympanic cavity. The contribution of the rostral and caudal parts to the entotympanicum differs greatly among the mammalian species and can be used as a characteristic to subdivide mammalian genera and families.

\subsection{Phylogeny of the bulla auditiva}

In the introduction of his impressive study on the bulla auditiva in fossil mammals van der Klaauw states that "his investigation .... on the development 
of the auditory bulla in recent mammals ....taught me the importance of the tympanic region both in comparative anatomy and as a factor in the determination of the relationships of genera and larger groups" (v/d kl 35). The latter aspect is still an important issue in palaeontological studies of mammals (see below). The structure of this paper is characteristic for van der Klaauw: in about 290 pages he described presence, shape, size and other aspects of all elements of the bulla auditiva and surrounding area. Again and again he discusses systematically all aspects of each of the bony elements throughout the groups of recent and fossil mammals, thus surveying the data from the literature and incorporating own observations. In doing so he typifies the auditory bulla of the respective genera and families At the end he summarizes in 34 pages his own observations on the tympanic and entotympanic in 47 specimen belonging to 20 genera of fossil mammals. In several publications van der Klaauw provides data about other groups of fossil mammals (v/d kl 27-29, 36)

\subsection{Impact of his work in recent studies}

As said before, knowledge of the auditory bulla is used to establish relationships between groups of fossil mammals. In this type of studies one relies on previous studies as long as the original observations seem correct. In this context it is interesting to note that several recent papers concerning the auditory area in fossil mammals refer to the work of van der Klaauw. For example, Bloch and Silcox (2001), discussing newly found basicrania of Ignacius, and Gaudin and Wible (1999) about the entotympanic of Pangolins, refer to $\mathrm{v} / \mathrm{dkl} 3 \mathrm{~A}$ and 35 . The latter paper is also mentioned in among others Wiig (1985), Novacek (1985), Springer (1998), Ivanoff (2001), Meng et al. (2003), Horovitz and Sanches-Villagra (2003), Wible et al. (2001, 2004, 2005). Several papers on other skeletal elements refer to papers by van de Klaauw, e.g., Sanches-Villagra et al. (2002) and Wible (2003) mention the paper about skeletal elements in the in the tendon of the musculus stapedius (v/dkl 6). This overview does not pretend to be exhaustive, but serves to give an impression of the importance of the early work of van der Klaauw.

\section{Ecology and ecological morphology}

In the years 1935-1936 van der Klaauw published three theoretical papers on the relatively new field of ecology (v/dkl 59, 61 and 62). In 1948 a fourth paper about ecological morphology followed. He also presented his ideas to national $(\mathrm{v} / \mathrm{dkl} 83,90,92)$ and international $(\mathrm{v} / \mathrm{dkl} \mathrm{85,} \mathrm{86)} \mathrm{forums.} \mathrm{The} \mathrm{first} \mathrm{point} \mathrm{he}$ wanted to make is that ecology as a new biological discipline is more than a simple form of natural history. The second is that this new area needs a set of concepts and definitions to give it a proper place in the array of biological disciplines. The aim of van der Klaauw was to provide (part of) this theoretical framework. 
In the first of the series of papers van der Klaauw tackles the problem of the significance of the idea of teleology for the logic of ecology, reverting to the philosophy of Kant (v/dkl 59; also v/dkl 97). The central question is that of the teleological cause in the relation of organism and abiotic nature as well as in the relations between organisms (herbs and herbivores; prey animals and carnivores etc.). Van der Klaauw summarizes the views of Tschulok, Driesch and von Uexküll. Following Kant, van der Klaauw considers teleological explanations 'as if' explanations, i.e., as a matter of non-causal relations. He discusses the difference between autecology (Autökologie) and synecology (Synökologie), that is the ecology on the individual and the supra-individual level, respectively.

In the second paper van der Klaauw discusses a set of definitions beginning with those formulated by Haeckel ( $\mathrm{v} / \mathrm{dkl} 61)$. The subdivision of ecology into aut- and synecology is the topic of the third paper ( $\mathrm{v} / \mathrm{dkl} 62)$. The three papers have a strong theoretical character referring to many older publications, but with hardly any reference to practical research. As such, these papers may be useful to people interested in the early development of ecology as a biological discipline. However, the strong theoretical approach, the style of writing, and the fact that these papers are written in German may have diminished their accessibility for many researchers.

The fourth and final paper of this series (in English; v/dkl 77) has a different scope and character discussing the connection between morphology and ecology. In fact, Böker was the first to introduce the field of ecological morphology (references in v/dkl 77). It was defined as the study of the morphological features in connection with environmental factors. In the vision of van der Klaauw it concerns the relation between the size and shape of individual organisms and their surroundings ( $\mathrm{v} / \mathrm{dkl} 77)$. In autecology such a relation is teleological as the individual and its parts should fit the environment (adaptation; also v/dkl 59, 62). Van der Klaauw discusses extensively Böker's approach pointing out that Böker 'nowhere openly admits a teleological point of view', which may be due to an interpretation of teleology as finality. Van der Klaauw goes on discussing the question whether the study of the morphology of the different organs also belongs to ecological morphology, as ecology regards whole animals and not parts of animals. His answer to this question is positive. Then, van der Klaauw formulates a series of questions about the relation between structure of organs and organisms, and the environment. Just to mention a few: By what qualities and characteristics does the structure fit the surroundings and to what degree does this interfere with adaptation? How does the structure of an organ fit the surroundings in which it performs its function? Do a number of organs cooperate to perform one function? What is the consequence of a certain function performed by one or a number of organs for other functions? Several of these questions already reflect the change of van der Klaauw's thinking in comparative terms into thinking in functional terms. This part of his study is peppered with a large number of examples. 
Bock (1990) re-introduced the field of ecological morphology or-in his terminology-ecomorphology, referring to the work of Böker and van der Klaauw. He considers this a neglected area and notes that the paper of van der Klaauw (v/dkl 77) has been overlooked, even by the group of Leiden functional morphologists. Indeed, Dullemeijer did not mention these papers in his book on animal morphology (Dullemeijer 1974). Even though around 1980 a group Ecological Morphology was established in Leiden, the ecology papers by van der Klaauw are not mentioned in their publications (e.g., Witte et al. 1983, Witte 1984). However, in a comparison of the methodologies of ecology and morphology Dullemeijer (1980) used the ecology studies of van der Klaauw.

Hagmeier and Stults (1964) casually mention v/dkl 77. After Bock, to my knowledge Liem (1993) was initially the only one to refer to this paper in a review of the ecomorphology of the teleost skull. Lately, interest in ecological morphology and in van der Klaauw's contribution has increased (e.g., Breda et al. 2005).

\section{Functional morphology}

\subsection{A new approach in morphology}

The most important contribution of van der Klaauw is the introduction of a new approach in functional morphology. His most influential papers may be those introducing new concepts in functional morphology (v/dkl 78, 84, 87), as well as that about the cerebral skull and facial skull (v/dkl 72). During the war 1940-1945 van der Klaauw was taken hostage by the occupying German authorities and spent some time in the German civil concentration camp St Michielsgestel (The Netherlands). He used this time to write a survey of the data on the Vertebrate skull from the literature. This resulted after the war in the series of papers on the architecture of the skull (v/dkl 78, 84, 87). In these papers van der Klaauw introduced two new cohering concepts. The first one is that of the functional component. Skeletal elements together performing a specific function should be considered as a unit with a certain degree of independence. The second concept is that of holism: the various functional components should fit together within the whole of the skull. For the latter aspect van der Klaauw may be inspired by the book Holism and Evolution (Smuts 1926). Van der Klaauw was able to make the concept of holism operational by introducing the functional component in functional morphology. In his paper on the distinction of the facial skull and the cerebral skull he considered these as relatively independently varying units. Initially, he used the term functional component for cranial elements, later on the weak parts were included. From 1950 on he started with his students a series of studies about the head anatomy of fishes, birds and mammals including the weak parts. Many of these studies resulted in publications (see: list of publications by students communicated by Van der Klaauw). However, even though the 
approach was a functional morphological one, the functional interpretations were mainly based on observations in dead animals.

\subsection{Impact of his papers on functional morphology}

The concept of the functional component was rather loosely defined by van der Klaauw. However, he laid the foundation, on which his student and successor Dullemeijer could build the theoretical framework of the functional morphology in a holistic context. Moreover, Dullemeijer introduced the functional analysis in life animals as part of functional morphological studies. For details of his contributions, see Dullemeijer (1974), Dullemeijer and Zweers (1997), and Dubbeldam et al. (1989) and the references therein. From 1960 the Leiden functional morphology was a thriving research area, internationally known as the Leiden school of functional morphology. The importance of the approach of van der Klaauw has been recognized by many researchers in various fields of morphology (e.g., Hanken, 1983; Cheverud, 1982), though not everybody was convinced. Thus Gans (1969) preferred the term mechanical unit over functional component. Liem (1989) used the term functional unit in a comparable way. The main difference is that the term unit implies a sharply bordered element, whereas functional components more or less fade into each other depending upon the influence of the function. Most influential in favor of the ideas of the ideas of van der Klaauw was the American orthodontist Moss who introduced the concept of the functional matrix in orthodontics (Moss and Young 1960). This concept rests upon the same assumptions as that of the functional component. Through the papers of Moss and his coworkers other researchers discovered the work of van der Klaauw, and recognized its significance for their own research , e.g., Radinsky (1985), Anton, (1989), Tollaro et al. (1994), Dressino and Pucciarelli (1997), Carlson (1999), Perlyn et al. (2001), Gonzáles-José et al. (2005), and Kikuchi (2005). The papers were mentioned in several chapters in Hanken and Hall (1993) and were also the subject of a recent theoretical analysis (Dressino and Lamas 2003). Even though the term functional component is hardly used anymore, the holistic approach of van der Klaauw still has a place in functional morphology of the head, as well of other systems (e.g., Adams 1998).

Van der Klaauw's last contribution to functional morphology was still more typology than functional morphology. In an extensive study he provides an exhaustive enumeration of types of muscle attachments and related specialization of skeletal areas of attachments (v/dkl 100). Even so, the paper proved to be useful to several authors, e.g., Anton (1999) and Zusi (in Hanken and Hall, 1993).

\section{Lecture notes}

It was already mentioned that Van der Klaauw prepared hand-outs with lecture notes for his students. These notes have a strong theoretical character 
and are interlarded with numerous examples offering references to anatomical data. His style of writing is exemplified in his last publication (v/dkl 104), more or less an English version of these notes. This paper was preceded by another theoretical study (v/dkl 103). This paper consists of thirty-one statements, in which van der Klaauw expressed his opinion about the importance of the philosophic backgrounds of the biological sciences. After completing these papers van der Klaauw was unable to continue his scientific activities because of serious health problems. Therefore, it is gratifying to note that these papers also have found their way in the more theoretical literature (e.g., Liem 1967; Sattler 1984; Young 1993).

\section{Concluding remarks}

Van der Klaauw published about several other topics, among others about theoretical issues (e.g., v/dkl 38, 39, 45, 64) and historical issues (e.g., v/dkl 33, $41,46,54,58,65)$. However, his most important contributions were in craniology. But here too, his contributions have a different weight. Whereas the references to his publications on the auditory region have to do with observations in specific species, have those on functional morphology a more fundamental and lasting impact on the methodology in functional and evolutionary morphology. As for ecological morphology, the connection between morphological features of the organism and the environment is often implicit in functional morphological studies.

In his capacity of director of the Zoological Laboratory of Leiden University, van der Klaauw had a long lasting impact on the development of this institute. He initiated several new lines of research e.g., theoretical biology, histology. During his directory Tinbergen began his studies in Ethology, Kuenen in Ecology. The short overview of the present paper shows that he was not only an inspiring teacher and an able administrator, but also a gifted scientist, who opened new vistas, in particular for functional morphology. The laboratory bearing his name may disappear, his merits will still be recognized for some time.

\section{Appendix 1}

Papers By Van Der Klaauw

1921

1. C.J. van der Klaauw, Scymnorhinus licha (Bonnaterre). Tijdschrift der Nederlandsch Dierkundige Vereeniging Ser. 2, 18, CIV-CIX.

2. C.J. van der Klaauw, Het entotympanicum, meer in het bijzonder bij Procavia. Nederlands Tijdschrift voor Geneeskunde, Jaargang 1921. (II, 15), 1916-1918. 
1922

3. C.J. van der Klaauw, Über die Entwicklung des Entotympanicums. Proefschrift, Leiden: Brill Id. in: Tijdschrift der Nederlandsche Dierkundige Vereeniging., Ser 2, 18 (2), 135-176.

4. C.J. van der Klaauw, Broman's zijlijnresten bij embryo's van Crocodilus porosus Schneider. Nederlands Tijdschrift voor Geneeskunde, Jaargang 1922 (II, 20), 2225-2227.

5. C.J. van der Klaauw, Historique de l'osselot ou du cartilage situé dans le tendon du muscle de l'étrier. Janus 26, 260-273.

1923

6. C.J. van der Klaauw, Die Skelettstückchen in der Sehne des Musculus stapedius und nahe dem Ursprung der Chorda tympani. Zeitschrift für Anatomie und Entwicklungsgeschichte. 69, 32-83.

1924

7. C.J. van der Klaauw, Über das Skelettstückchen von Paauw und den Verlauf der Chorda tympani bei einigen Marsupialia. Anatomische Anzeiger. 57 (12), 240-246.

8. C.J. van der Klaauw, Bau und Entwickelung der Gehörknöchelchen. Literatur 1899-1923. Ergebnisse. Anatomie und Entwicklung 25, 565-622.

9. C.J. van der Klaauw, Eenige skeletstukjes in de trommelholte bij de zoogdieren. Tijdschrift der Nederlandsche Dierkundige Vereeniging, Ser 2, 19 (1/2), III-VIII.

10. C.J. van der Klaauw, Over den loop van de Chorda tympani bij Trichosurus. Nederlands Tijdschrift voor Geneeskunde, Jaargang 68 (11), 1217-1219.

11. C.J. van der Klaauw, De opleiding van studenten in de zoologie aan enkele Amerikaansche universiteiten. Vakblad voor Biologen. 5 (7), 97108.

12. C.J. van der Klaauw, Zoologische reisindrukken uit Amerika. Vakblad voor Biologen 5 (11), 161-173.

13. C.J. van der Klaauw, Over de ontwikkeling van de tympanaalstreek bij eenige zoogdieren. Nederlands Tijdschrift voor Geneeskunde, Jaargang 68 (15), 3-7.

14. C.J. van der Klaauw, Waarnemingen in Amerikaansche musea over de tympanaalstreek van fossiele zoogdieren. Tijdschrift der Nederlandsche Dierkundige Vereeniging. Ser. 2, 19 (3), CXVIII-CXIX. 
1926

15. C.J. van der Klaauw, Het hooger onderwijs in de zoölogie en zijne hulp-middelen te Leiden. Een historische schets naar aanleiding van het 50-jarig bestaan van het tegenwoordige Zoölogische Laboratorium. Sijthoff, Leiden, 131 p.

16. C.J. van der Klaauw, Het 50-jarig bestaan van het Zoölogisch Laboratorium te Leiden. Vakblad voor Biologen 7, 131-132.

17. C.J. van der Klaauw, Nadere gegevens omtrent de universitaire studie in de zoölogie te Leiden. Vakblad voor Biologen 8 (1), 11-18.

18. C.J. van der Klaauw, Waarvoor studeeren wij? De Smidse, 2, 33-43, 8393.

19. C.J. van der Klaauw, Het programma van de acte K IV. Vakblad voor Biologen 8 (9), 169-182.

20. C.J. van der Klaauw, De opleiding van den leeraar in de biologie. Vragen des Tijds, 354-380.

21. C.J. van der Klaauw, Het nieuwe wetsontwerp op het Voorbereidend Hooger Onderwijs en het Middelbaar Onderwijs en de Biologie. Vakblad voor Biologen 9 (8), 139-143.

22. C.J. van der Klaauw, On the development of the tympanic region of the skull in the Macroscelididae. Proceedings of the Zoological Society, London, p. 3, 491-560.

23. C.J. van der Klaauw, Technische of biologische bestrijding van plagen der cultuurgewassen? Een kwestie van economische zoölogie of ook een zaak van wereldbeschouwing? De Smidse 4 (4), 101-112.

24. C.J. van der Klaauw, De beteekenis van vijanden en parasieten in de dierenwereld. De Smidse 4 (12), 358-369.

25. C.J. van der Klaauw, De middelbare acte K IV. Examinatoren en geëxamineerden. Leidsche Bijdragen voor Opvoedkunde en Zielkunde. I, 81-98.

26. C.J. van der Klaauw, De loop van het aantal studenten in de biologie. Vakblad voor Biologen 11 (4), 63-68.

27. C.J. van der Klaauw, La région tympanique du crâne du Megatherium. Tijdschrift der Nederlandsche. Dierkundige Vereniging 3e ser., dl II (2), 77-82. 
28. C.J. van der Klaauw, La région tympanique du crâne du Scelidotherium. Tijdschrift der Nederlandsch Dierkundige Vereniging 3e ser., dl II (2), 83-87.

29. C.J. van der Klaauw, On the tympanic region of the skull in the Megatherium. Proceedings of the Zoological Society, London, p.1, 127-146.

30. C.J. van der Klaauw, On mammalian auditory bullae showing an indistinctly complex structure in the adult. Journal of Mammalogy 11, $55-60$.

31. C.J. van der Klaauw, De wijziging van het Academisch Statuut en de biologie. Vakblad voor Biologen 12 (2), 26-29.

32. C.J. van der Klaauw, Inleiding tot de zoö-morphologische techniek met uitsluiting van de microtoomtechniek. Duyverman, Oegstgeest, $41 \mathrm{p}$.

33. C.J. van der Klaauw, Een verzameling uit den eersten tijd van de vergelijkende ontleedkunde (de collectie Brugmans). De Natuur 50, 4953, 73-78, 97-101, 122-126.

34. C.J. van der Klaauw, Nuttige en schadelijke dieren. De Natuur, 50, 202208, 225-233, 253-261, 273-275.

35. C.J. van der Klaauw, The auditory bulla in some fossil mammals. Bulletin of the American Museum of Natural History 62, 1-352.

36. C.J. van der Klaauw, On the tympanic region of the skull in the Mylodontinae. Proceedings of the Zoological Society, London (3) 607655.

37. C.J. van der Klaauw, Plaats, omvang en betekenis der morfologie in verband met het systeem der biologie. Openbare Les, Leiden. Sijthoff, Leiden, $28 \mathrm{p}$.

38. C.J. van der Klaauw, Kritische Bemerkungen zur Normbegriff bei Rautmann und Lubosch, Tijdschrift der Nederlandsche Dierkundige Vereniging, Ser.3, 2 (4), 221-230.

39. C.J. van der Klaauw, Normaal, norm en normbegrip in de biologie. Vakblad voor Biologen 12 (9), 173-183.

40. C.J. van der Klaauw, De biologische afdeeling van het Nederlandsch Historisch Natuurwetenschappelijk Museum te Leiden. Vakblad voor Biologen 12 (10), 189-197.

41. C.J. van der Klaauw, A letter of B.S. Albinus from Leiden to R. Nebitt in London. Janus 35, 4 p.

42. C.J. van der Klaauw, Een brief van den theologischen Hoogleraar Clarisse aan zijn leerling in de natuurlijke historie, den lateren hoogleraar Jan van der Hoeven. Nederlands Tijdschrift voor Geneeskunde. 75, 4561-4564.

43. C.J. van der Klaauw, Het normbegrip. Handelingen van het. XXIIIe Nederlandse Natuur- en Geneeskundige Congress, 3 p. 
44. C.J. van der Klaauw, De studentenbevolking van de Faculteiten der Geneeskunde en der Wis- en Natuurkunde sinds 1818, in het bijzonder te Leiden. Nederlands Tijdschrift voor Geneeskunde 75 (18), 2381-2990.

1932

45. C.J. van der Klaauw, Kritische Bemerkungen über das System der Biologie von Lubosch. Tijdschrift der Nederlandsche Dierkundige Vereeniging. Ser. 3, 3 (1), 9-36.

46. C.J. van der Klaauw, The scientific correspondence between professor Jan van der Hoeven and professor Richard Owen. Janus 36, 1-25.

47. C.J. van der Klaauw, Inhoud en opzet van de Landbouwdierkunde. Maandblad voor het Nederlandse Genootschap voor ILandbouwwetenschappen 44, 599-606.

48. C.J. van der Klaauw, De biologenbetrekkingen in Nederland. Vakblad voor Biologen 13 (12), 1-16.

49. C.J. van der Klaauw, Godsdienstig geloof en biologie. De Smidse 7, 287-299.

50. C.J. van der Klaauw, Lijst van enige technische termen, gebruikelijk in de vergelijkende ontleedkunde. Sijthoff, Leiden, 24 p.

51. C.J. van der Klaauw, Handleiding bij de dierkunde-practica voor medische studenten. Sijthoff, Leiden, 78 p.

52. C.J. van der Klaauw, Biologie in harmonie en in conflict met het godsdienstig geloof. De Smidse 8, 72-86.

53. C.J. van der Klaauw, Godsdienstige wereldbeschouwing en de denkdoeleinden in de biologie. De Smidse 8, 241-248.

54. C.J. van der Klaauw, Oude microtomen in het Nederlandsch historisch natuurwetenschappelijk museum te Leiden. Nederlands Tijdschrift voor Geneeskunde 78 (40), 4549-4557.

55. C.J. van der Klaauw, Uitwendige doelmatigheid en einddoel bij Kant en in de moderne biologie. Oratie. Brill, Leiden, $42 \mathrm{p}$.

56. C.J. van der Klaauw, Het oude mechanisme en het daaraan voorafgaande en het daarop volgende vitalisme en hun betrekking tot het godsdienstig geloof. De Smidse, 9, 65-77, 97-102, 130-142.

57. C.J. van der Klaauw, Boekbespreking: E.D. Baumann, De harmonie der dingen. Drie studies over doeloorzaken en doelmatigheid in de natuur. Barchem Bladen 9 (5), 161-162.

58. D.C. Geyskes, C.J. van der Klaauw, Der heutigen Zustand der anatomischen Kabinette früherer Jahrhunderte in Leiden. Janus 38, 14 p. 
1935

59. C.J. van der Klaauw \& A. Meyer, Ökologische Studien und Kritiken. I. Die Bedeutung der Teleologie Kants für die Logik der Ökologie (C.J. van der Klaauw). Sudhoffs Archiv für Geschichte der Medizin und der Naturwissenschaften. 27 (6), 516-588.

60. C.J. van der Klaauw, Handleiding bij de dierkunde practica voor medische studenten, 2e druk. Sijthoff, Leiden, 86 p.

61. C.J. van der Klaauw, Ökologische Studien und Kritiken: II Zur Geschichte der Definitionen der Ökologie, besonders auf Grund der Systeme der zoologischen Disziplinen. Sudhoffs Archiv für Geschichte der Meddizin und der Naturwissenschaften. 29, (3), 136-177.

62. C.J. van der Klaauw, Ökologische Studien und Kritiken. III Zur Aufteilung der Ökologie in Autökologie und Synökologie, im lichte der Ideen als grundlage der Systematik der Zoologischen Disziplinen. Acta Biotheoretica, Ser. A, 2 (3), 195-241.

63. C.J. van der Klaauw, G.J. van Oordt. Technische termen ten gebruike bij het propedeutisch zoologisch onderwijs aan de Nederlandsche universiteiten. Brill, Leiden, 90 p. 1938: 2e herziene druk, 1941 3e, geheel herziene druk; 1951, 4e druk.

64. C.J. van der Klaauw, La Fondation Jan van der Hoeven pour la biologie théorique à Leyde. La Presse Médicale 43 (29 Mai), 8 p.

65. C.J. van der Klaauw, Het eertijds verplichte instrumentarium van den heelmeester. Nederlands Tijdschrift voor Geneeskunde 83 (26), 3343-3353.

66. C.J. van der Klaauw, Skelet van de kop. In: J.E.W. Ihle, Leerboek der Vergelijkende Ontleedkunde van de Vertebraten, 2nd ed. Vol I, Utrecht: Oosthoek; pp. 223-282.

67. C.J. van der Klaauw, Het eertijds verplichte instrumentarium van den vroedmeester. Nederlands Tijdschrift voor Geneeskunde 84 (49), 4814-4823

68. C.J. van der Klaauw, Theoretische Biologie. Vakblad voor Biologen 21 (5), 75-88.

69. C.J. van der Klaauw, Twee brieven van Georges Cuvier aan Jan van der Hoeven. Nederlands Tijdschrift voor Geneeskunde 86 (40), 2473-2475.

70. C.J. van der Klaauw, Het eertijds verplichte instrumentarium van de vroedvrouw. Nederlands Tijdschrift voor Geneeskunde 86 (45), 27902796. 
71. C.J. van der Klaauw \& J.M. van Roon, Fenestra medio-palatinalis und Interpterygoidalspalt. Archives Néerlandaises de Zoologie 6 (4), 327-340.

72. C.J. van der Klaauw, Cerebral skull and facial skull. A contribution to the knowledge of skull-structure. Archives Néerlandaises de Zoologie 7 $(1 / 2), 16-37$.

73. C.J. van der Klaauw, Inleiding. In: J.E.W. Ihle, Leerboek der vergelijkende ontleedkunde van de Vertebraten. 3rd ed. Vol. I. Utrecht: Oosthoek, Utrecht, 1-19.

74. C.J. van der Klaauw, Skelet van de kop. Id., 245-309.

75. C.J. van der Klaauw, Bouw en levenswijze der dieren. Natuurkundige Voordrachten, Diligentia, Nieuwe Reeks 23/24, 22-28.

76. C.J. van der Klaauw, Practicum-handleiding vergelijkende ontleedkunde der gewervelde dieren. 4e druk, Brill, Leiden, 104 p.

77. C.J. van der Klaauw, Ecological studies and reviews. IV. Ecological Morphology. Bibliographia Biotheoretica 4 (2), 23-111.

78. C.J. van der Klaauw, Size and position of the functional components of the skull. A contribution to the knowledge of the architecture of the skull, based on data in the literature. Archives Néerlandaises de Zoologie 9, 1-176.

79. C.J. van der Klaauw, Science in the Netherlands since the end of the war. Experientia IV (8), 323.

80. C.J. van der Klaauw, 1. Wat is Biologie. 2. Algemene begrippen, logica en wiskunde. 7. Morfologie en anatomie der dieren. 13. Cel- en weefselleer der dieren. 16. Oecologie. 18. Dierenoecologie en-eografie. A. Autoecologie der dieren; B. Synoecologie en biosociologie der dieren, zoöcoenologie. 26. Pathologie der dieren. 27. Mechanisme, vitalisme en holisme. 29. Metabiologie. 30. Theoretische biologie. In: C.J. van der Klaauw, H.J. Lam, G.O.E. Lignac (eds). E.N.S.I.E., VI, Amsterdam, pp. 2-3, 3-9, 48-54, 101-107, 126-127, 157-170, 212-215, 215, 217, 219-221, 221.

81. C.J. van der Klaauw, De verschillende aspecten van het aanpassingsprobleem. Vakblad voor Biologen 29 (8) 137-149.

1950

82. C.J. van der Klaauw, Architectuur van de schedel. Verslag Koninklijke Akademie van Wetenschappen,. 59 (3), 1-7.

83. C.J. van der Klaauw, Internationaal symposion over oecologie te Parijs. Vakblad voor Biologen 30 (5), 81-93. 
1951

84. C.J. van der Klaauw, Size and position of the functional components of the skull. A contribution to the knowledge of the architecture of the skull, based on data in the literature (cont.d). Archives Néerlandaises de Zoologie 9, 177-368, plates III-VIII.

85. C.J. van der Klaauw, Bau, Lebensweise und Milieu der Tiere. Die Grundlagen einer oekologischen Morphologie. Vortrag. Acta Societas Fauna et Flora Fennica. 67 (2), 1-18.

86. C.J. van der Klaauw, Qu'est-ce que l'écologie. Année Biologique 27 (2), 103-115. 1952

87. C.J. van der Klaauw, Size and position of the functional components of the skull. A contribution to the knowledge of the architecture of the skull, based on data in the literature (contd.). Archives Néerlandaises de Zoologie 9, 369-559.

1953

88. C.J. van der Klaauw, Dertig jaar biologische studie te Leiden. Kameleon (lustrumnummer), 5-9.

89. C.J. van der Klaauw, 121/2 jaar Itbon. T.N.O.-Nieuws 8 (85), 1-4.

1954

90. C.J. van der Klaauw, Wat is oecologie. Proceedings. Koninklijke Nederlandse Akademie van Wetenschappen, Ser. C 57 (4), 390-401.

91. C.J. van der Klaauw, Practicum-handleiding vergelijkende ontleedkunde der gewervelde dieren. 6e druk. Brill, Leiden, 104 p.

92. C.J. van der Klaauw, Het eigen karakter van de oecologie als biologische wetenschap. Faraday.

1956

93. C.J. van der Klaauw, Schedelrelief en spieraanhechting. Verslag gewone vergadering van de Koninklijke Nederlandse Akademie van Wetenschappen, afd Natuurkunde 65 (6), 73-77.

1958

94. C.J. van der Klaauw, Biology and philosophy. In: R. Klibansky (ed) Philosophy in the mid-century. A survey. Firenze: La Nuova Italia Editrice, pp 315-328.

95. C.J. van der Klaauw, Om der wille van de wetenschap ...!? Leidse Voordrachten 26, Universitaire Pers Leiden, 14 pp.

96. C.J. van der Klaauw, De schedel van een aberrante neushoornvogel, Rhinoplax vigil (Forst.). Verslagen van de Koninklijke Nederlandse Akademie van Wetenschappen, afd Natuurkunde 68 (7), 112-115. 
97. C.J. van der Klaauw, Teleologie in de moderne biologie. Algemeen Nederlands Tijdschrift voor Wijsbegeerte en Psychologie 52 (2), 68-79.

98. C.J. van der Klaauw, Rapport over de 'Celebrazione Spallanzaniana. Symposio internazionale di biologia sperimentale'. Rapport Koninklijke Nederlandse Akademie van Wetenschappen, 11 (1), 3-5.

99. C.J. van der Klaauw, Verklaren, begrijpen, waarheid en zekerheid in de biologie. Annalen van het Genootschap voor Wetenschappelijke Philosophie 33 (2), 101-117.

1963

100. C.J. van der Klaauw, Projections, deepenings and undulations of the surface of the skull in relation to the attachment of muscles. Verhandelingen van de Koninklijke Nederlandse Akademie van Wetenschappen, 2e ser, 55, $247 \mathrm{pp}$.

101. C.J. van der Klaauw, Levensbericht van Max Hartmann, Jaarboek Koninklijke Nederlandse Akademie van Wetenschappen, 1962/1963, 7 pp.

1964

102. C.J. van der Klaauw, Hilbrand Boschma. Zoologische. Mededelingen 39, 9-49.

103. C.J. van der Klaauw, Elements for an objective and neutral introduction to the philosophic backgrounds and prospects of the biological sciences. Proceedings of the Royal Dutch Academy of Sciences. Ser C 67 (3), 119-127.

104. C.J. van der Klaauw, Introduction to the philosophic background and prospects of the supraspecific comparative anatomy of conservative characters in the adult stages of conservative elements of Vertebrata with an enumeration of many examples. Proceedings of the Royal Dutch Academy of Sciences. 2e reeks 57 (1), 196 p.

\section{Appendix 2}

Publications By Students Of Van Der Klaauw 1950

A.M. Husson: Some remarks on prognathism with special reference to the skull of Pongo pygmaeus (Hoppius). Proceedings of the Royal Dutch Academy of Science. 53 (2): 199-210. 
1951

E. Arendsen de Wolff-Exalto: On differences in the lower jaw of animalivorous and herbivorous mammals. I. Proceedings of the Royal Dutch Academy of Science, Ser. C, 54 (3): 237-246; II. Ibid. 54 (4): 405-410.

P. Dullemeijer: The correlation between muscle system and skull structure in Phalacrocorax carbo sinensis (Shaw and Nodder). I. Proceedings of the Royal Dutch Academy of Science, Ser.C, 54 (3): 247-259; II. Ibid. 54 (4): 400-404; III Ibid. 54 (5): 533-536; IV. Ibid. 55 (1): 95-102 (1952).

M. Duym: On the head posture in birds and its relation to some anatomical features. I. Proceedings of the Royal Dutch Academy of Sciences, Ser. C, 54 (2): 202-211; II. Ibid. 54 (3): 260-271.

R.D. Hoogland: On the fixing-mechanism in the spines of Gasterosteus aculeatus L. Proceedings of the Royal Dutch Academy of Sciences, Ser. C, 54 (2): 171-180.

V. Manger Cats: On the correlation between the muscles and the skull structure in the regio occipitalis and the regio otica of some Squaliformes. I. Proceedings of the Royal Dutch Academy of Sciences, Ser. C, 54 (2): 191201; II. Ibid. 54 (3): 296-300.

1952

J. van den Assem: The relation between muscles and skull structure in the regio branchialis in Squalus acanthias L. Proceedings of the Royal Dutch Academy of Sciences, Ser. C, 55 (5): 656-674.

H.L. Booy: The bony horn-core in Connochaetes gnou (Zimmermann). Proceedings of the Royal Dutch Academy of Sciences, Ser. C, 55 (4): 514-524. E.K.P. Cool: The correlation between muscle attachment and skull structure in Rana esculenta L. I. Proceedings of the Royal Dutch Academy of Sciences, Ser. C, 55(5): 634-643. II/III. Ibid. 56 (2): 228-243 (1953).

J.A.G. Davids: Etude sur les attaches au crâne des muscles de la tête et du cou chez Anas platyrhyncha platyrhynga (L.). I. Proceedings of the Royal Dutch Academy of Sciences, Ser. C, 55 (1): 81-94; II/III. 55 (4):525-540.

\section{3}

P.J. den Boer: On the correlation between the cervical muscles and the structure of the skull in Phasianus colchicus L. and Perdix perdix L. I. Proceedings of the Royal Dutch Academy of Sciences, Ser. C, 56 (3): 335345; II. Ibid. 56 (4): 455-473.

A.M. Husson: On the foramen magnum occipitale and some other skullmeasurements of Cricetus cricetus canescens Nehring with respect to sexual dimorphism. I/II. Proceedings of the Royal Dutch Academy of Sciences, Ser. C, 56 (5): 609-630. 
H.R. van der Vaart: On certain statistical methods used in biology with special reference to Husson's paper on Cricetus cricetus canescens Nehring. Proceedings of the Royal Dutch Academy of Sciences, Ser. C., 56 (5): 631638.

N.H. van Vendeloo: On the correlation between the masticatory muscles and the skull structure in the muskrat, Ondatra zibethica (L.). I. Proceedings of the Royal Dutch Academy of Sciences, Ser. C, 56: (1): 116-127; II. Ibid. 56 (2): 265-277.

A.G. Vlasblom: The lower jaw of the parrots (Psittaciformes) in relation to the architecture of the skull. Proceedings of the Royal Dutch Academy of Sciences, Ser. C, 56 (4): 486-507.

1954

C. Bas: On the relation between the masticatory muscles and the surface of the skull in Ardea cinerea (L.). I. Proceedings of the Royal Dutch Academy of Sciences, Ser. C, 57 (5)678-685.

P.D. Burggraaf: On the correlation between the skull structure and the muscles in the male Phasianus colchicus L. II. The attachment of the musculus adductor mandibulae externus. Proc. Roy. Acad. Sci., Ser. C, 57 (3): 292-303; V. The attachment of the musculus mylohyoideus and of the musculus geniohyoideus. Ibid. 57 (5): 673-677.

P.D. Burggraaf, A Fuchs: On the correlation between the skull structure and the muscles in the male Phasianus colchicus L. I. General introduction. Proceedings of the Royal Dutch Academy of Sciences, Ser. C., 57 (3): 286291. VII. General considerations. Ibid. 58 (1): 98-100.

A. Fuchs: On the correlation between the skull structure and the muscles in the male Phasianus colchicus L. III. The attachment of the musculus adductor mandibulae posterior and the musculus adductor mandibulae internus. Proceedings of the Royal Dutch Academy of Sciences, Ser. C, 57 (4): 454-470; IV. The attachment of the musculus protractor quadrati et pterygoidei and of the musculus depressor mandibulae. Ibid. 57 (5): 666-672; VI. Some remarks on a number of ligaments and other connective tissue connections. Ibid. 58 (1): 114-120 (1955).

\section{5}

C. Bas: On the relation between the masticatory muscles and the surface of the skull in Ardea cinerea (L.). II/III. Proceedings of the Royal Dutch Academy of Sciences, Ser. C, 58 (1): 103-113; IV. Ibid 60 (4): 480-485 (1957).

J.W. de Blok: On the architecture of the asymmetrical head in Pleuronectes platessa L. I/II. Proceedings of the Royal Dutch Academy of Sciences, Ser. C, 58 ( ): 659-678; III. Ibid. 59 ( ): 240-247 (1956); IV. Ibid. 60 ( ): 77-89. 
1956

R.A. Bams: On the relation between the attachment of the jaw muscles and the surface of the skull in Podiceps cristatus L., with some notes on the mechanical properties of this part of the head. I/II. Descriptive part. Proceedings of the Royal Dutch Academy of Sciences, Ser. C, 59 (1): 82-101; III/IV. Descriptive part. Ibid 59 (2): 248-262.

J.J. Gottenbos: On the correlation between the muscles and the structure in the regio occipitalis and the regio otica in Raja batis L. I. Proceedings of the Royal Dutch Academy of Sciences, Ser. C, 59 (4): 541-553; II. Ibid. 59 (5): 723-737.

\section{8}

E. Goedbloed: The condylus occipitalis in birds. I/II/III. Proceedings of the Royal Dutch Academy of Sciences, Ser. C, 61 (1): 36-65.

B. Tulner: On the bulge of the dorsal surface of the cerebral skull in Perdix perdix L. and Phasianus colchicus L. Proceedings of the Royal Dutch Academy of Sciences, Ser. C, 61 (2): 207-212.

\section{1}

Ch. S.W. Manger Cats-Kuenen: Casque and bill of Rhinoplax vigil (Forst.) in connection with the architecture of the skull. Verhandelingen van de Koninklijke Nederlandse .Akademie van Wetenschappen.W., 2e Serie, 53, no 2, $51 \mathrm{pp}$.

\section{References}

Adams RA (1998) Evolutionary implications of development in functional integration in the bat wing. J Zool 246:165-147

Anton SC (1989) Intentional cranial fault deformation and induced changes of the cranial base and face. Am J Phys Anthropol 79:253-267

Anton SC (1999) Macaque Masseter Muscle: Internal Architecture, fiber length and cross sectional area. Int J Primatol 20:441-462

Bloch JC, Silcox MT (2001) New basicrania of Paleocene-eocene Ignacius: Re-evaluation of the Plesiadapiform-Dermopteran link. Am J Phys Anthropol 116:184-198

Bock WJ (1990) From Biologische Anatomie to ecomorphology. Netherlands J Zool 40:254-277

Boschma H (1968) Short Biography of Professor Dr C.J. van der Klaauw; Bibliography of C.J. van der Klaauw. Acta Biotheoretica A18:2-8

Boschma H (1958) A concise review of the scientific activities of C.J. van der Klaauw. Archives Néerlandaises de Zoologie 13(suppl. 1):5-9

Breda L, de Oliveira EF, Goulart E (2005) Ecomorfologia de locomoçăo de peixis con enfogne para espécies neotropicaŭs. Acta scientiarum, Biological Sciences 27:371-381

Brongersma LD (1972). Levensbericht van Cornelis Jacob van der Klaauw (16 november 18931920 mei 1972), Jaarboek Koninklijke Nederlandse Akademie van Wetenschappen (1972), $127-133$ 
Carlson DS (1999) Growth modification: from molecules to mandibles. In: McNamara JA (ed) Growth Modification: What Works, What Doesn't, And Why. Craniofacial Growth Series 35:17-62

Cheverud JM (1982) Phenotypic, genetic, and environmental morphological integration. Evolution 36:499-516

Dressino V, Lamas SG (2003) Teoría cranea functional de Cornelis Jacob van der Klaauw: una teoría sobre adaptación morfológica. Episteme, Porto Alegre 16:99-110

Dressino V, Pucciarelli HM (1997) Cranial growth in Saimiri sciureus (Cebidae) and its alteration by nutritional factors: a longitudinal study. Am J Phys Anthropol 102:545-554

Dubbeldam JL, de Jongh HJ, Osse JWM (1989) Pieter Dullemeijer, Professor of Animal Morphology. Acta Morphologica Néerlando-Scandinavica 27:9-16

Dullemeijer P (1974) Concepts and Approaches in Animal Morphology. Assen, Van Gorcum

Dullemeijer P (1980) Animal ecology and morphology. Netherlands J Zool 30:161-178

Dullemeijer P, Zweers GA (1997) The variety of explanations of living forms and structures. Eur J Morphol 35:354-364

Gans C (1969) Functional components versus mechanical units in descriptive morphology. J Morphol 128:365-368

Gaudin TJM, Wible JRM (1999) The entotympanic of Pangolins and the phylogeny of the Pholidota (Mammalia). J Mammal Evol 6:39-65

González-José R, Ramirez-Rozzi F, Sardi M, Martinez-Abadios N, Hernández M, Pucciarelli HM (2005) Functional-cranial approach to the influence of economic strategy on skull morphology. Am J Phys Anthropol 128:757-771

Hagmeier EM, Stults CD (1964) A numerical analysis of the distributional patterns of North American mammals. Syst Zool 13:125-155

Hanken J (1983) Miniaturization and its effects on cranial morphology in Plethodontic Salamanders, genus Thorius (Amphibia, Plethodontidae): II The fate of the brain and sense organs and their role in skull morphogenesis and evolution. J Morphol 177:255-268

Hanken J, Hall BK (eds) (1993) The Skull, vols 2, 3. University of Chicago Press, Chicago

Horovitz I, Sanches-Villagra MR (2003) A morphological analysis of marsupial mammal higherlevel phylogenetic relationships. Cladistics 19:181-212

Ivanoff DV (2001) Partitions in the carnivoran auditory bulla: Their formation and significance for systematics. Mamm Rev 31:1-16

Kampen PN van (1905) Die Tympanalgegend des Säugetierschädels. Morph Jahrb 34:321-722

Kikuchi MK (2005) Orthodontic treatment in children to prevent sleep-disordered breathing in adulthood. Sleep Breath 9:146-158

Liem KF (1967) A morphological study of Luciocephalus pulcher, with notes on gular elements in other recent teleosts. J Morphol 121:103-133

Liem KF (1989) Functional morphology and phylogenetic testing within the framework of symecomorphosis. Acta Morphologica Néerlando-Scandinavica 27:119-131

Liem KF (1993) Ecomorphology of the teleostean skull. In: Hanken J, Hall BK (eds) The skull, functional and evolutionary mechanisms, vol 3. The University of Chicago Press, Chicago, pp $422-452$

Meng JIN, Hu Y, Wang Y, Li C (2003) The ossified Meckel's cartilage and internal groove in Mesozoic mammaliaforms: implications to the origin of the definitive mammalian middle ear. Zool J Linn Soc 138:431-448

Moss ML, Young RW (1960) A functional approach to craniology. Am J Phys Anthropol 18:281292

Novacek MJ (1985) Evidence for echolocation in the oldest known bats. Nature 315:140-141

Perlyn CA, Marsh JL, Oilgram TK, Kane A (2001) Plasticity of the endocranial base in nonsyndromic craniosynostosis. Plast Reconstr Surg 108:294-301

Radinsky LB (1985) Approaches in evolutionary morphology: a search for patterns. Ann Rev Ecol System 16:1-14

Sánches-Villagra MR, Gemballa S, Nummela S, Smith KK, Maier W (2002) Ontogenetic and phylogenetic transformations of the ear ossicles in Marsupial mammals. J Morphol 251:219238

Sattler R (1984) Homology—a continuing challenge. Syst Bot 9:382-394 
Springer MS (1998) The origin of the Australasian marsupial fauna and the phylogenetic affinities of the enigmatic monitor del monte and marsupial mole. Proceedings of the Royal Society B 265:23-81

Smuts JC (1926) Holism and Evolution (reprint 1961). Viking Press New York, N.Y

Tollaro I, Baccetti T, Bassarelli V, Franchi L (1994) Class III malocclusion in the deciduous dentition: a morphological and correlation study. Eur J Orthod 16:401-408

Trienes R (1988) The influence of German Idealistic Morphology on the development of C.J. van der Klaauw's epistemology. Acta Biotheoretica 37:91-119

Wible JR (2003) On the cranial osteology of the short-tailed opossum Monodelphis brevicaudata (Didelphidae, Marsupialia). Ann Carnegie Mus 72(1):137-202

Wible JR, Novacek MJ, Rougier GW (2004) New data on the skull and dentition in the Mongolian late cretaceous Eutherian mammal Zalambdalestes. Aust J Zool 45:211-280

Wible JR, Rougier GW, Novacek MJ, McKenna MC (2001). Earliest eutherian ear region: a petrosal referred to Prokennalestes from the early Cretaceous of Mongolia. Novitates 3322, $44 \mathrm{pp}$

Wible JR, Wang Y, Li C, Dawson MR (2005) Cranial anatomy and relationships of a new Ctenodactyloid (Mammalia, Rodentia) from the early Eocene of Hubei Province, China. Ann Carnegie Mus 74:91-150

Wiig Y (1985) Relationship of Nandinia binotata (Gray) to the superfamily Feloidea (Mammalia, Carnivora). Zoologica Scripta 14:155-159

Witte F (1984) Ecological differentiation in Lake Victoria haplochromines: comparison of Cichlid species flocks in African lakes. In: Echelle AA, Kornfield I (eds) Evolution of species flocks. Orono, University of Maine at Orono Press, pp 155-167

Witte F, Barel CDN, Hoogerhoud RJC (1983) The ecological differentiation of two closely resembling Haplochromis species from Lake Victoria) (H. iris and H. hiatus; Pisces Cichlidae). Netherlands J Zool 33:283-305

Young B (1993) On the necessity of an archetypal concept in morphology: with special reference to the concepts of "structure" and "homology". Biol Philos 8:225-248 